\title{
CHAPTER 4 \\ BUDGETARY DECENTRALIZATION: THE STATUS AND PROSPECTS OF IMPLEMENTATION IN UKRAINE
}

\section{Lysiak L. V.}

\section{INTRODUCTION}

Over the years of independence, the budget system of Ukraine evolved under conditions of increased centralization of budget funds in the state budget. Despite the constitutional and legislative status of national self-government, this important social institute in Ukraine was in fact formal in nature and functioned inefficiently for years of independence.

The lack of institutional, organizational and financial conditions for exercising the right and ability of local governments to resolve local issues at their own expense has led to high dependency of local budgets on intergovernmental transfers, low efficiency of state and local budgets expenditures. Self-government bodies' financial failure, their passivity and irresponsibility in managerial decisions affected the deepening of the uneven development of Ukrainian regions, exacerbated social and economic risks and led to the necessity to look for the ways of the budget system functioning efficiency improvement.

The budgetary decentralization issue with different intensity has been raised during all the years of Ukraine development, simultaneously it has been given priority status since 2014. Formed and legally approved conceptual foundations for reforming local self-government, issues of redistribution of powers between levels of government and proper financial resources to fulfil them were the beginning of fundamental changes in the administrative and territorial units at local/locative levels development.

Budgetary decentralization problems complication and complexity, local budgets strengthening, intensification of their influence on regions socio-economic development prompted scientists to search the ways to improve the quality of financial support for the functions of the state and self-government bodies, to increase the efficiency of managing budget funds in order to reduce regional disparities, to increase financial disparities and governing bodies responsibility. The theoretical foundations of decentralization in general and financial decentralization in particular, financing/providing public services at different levels of government, local 
budgets development were laid out in foreign scientists' works: A. Wagner, W. Oates, V. Tanzi, C. Tiebout, R. Musgrave. Problems of realization of budgetary policy at the state and local levels, formation of financial potential of administrative-territorial units development, local budgets strengthening, optimization of their expenditures in the conditions of decentralization and European integration aspirations of Ukraine are devoted to the works of domestic scientists: O. Vasylyk, T. Bogolib, G. Voznyak, O. Grabchuk, O. Kyrylenko, M. Krupka, M. Kuzhelev, L. Lysiak, I. Lunina, I. Lukyanenko, V. Oparin, Y. Pasichnyk, Y. Radeletsky, I. Chugunov, V. Fedosov, S. Yuriy and others.

At the same time, public finances decentralization and the intergovernmental Ukraine budget system reforming continues and is accompanied by several problems. Budgetary decentralization processes in the aspect of local budget development, the extension of tax potential of generating budget revenues of the united territorial communities, and the expenditure planning improvement require further scientific research.

The purpose of this study is to analyze the budgetary decentralization theoretical foundations, to evaluate its practical implementation process and to outline the ways to strengthen local budgets in the context of deepening financial decentralization and increasing financial autonomy of local self-government in Ukraine.

The set of methods and techniques was applied in the work, which made it possible to realize the conceptual unity of research: analysis, grouping, systematic, comparative and others.

\subsection{Budget decentralization as a necessary condition for territorial development}

Centralization and decentralization are the basic principles of government formation. Decentralization is interpreted as the abolition/ weakening of centralization; it is a system of governance in which part of the central government functions is transferred to local self-government bodies $^{1}$. The theory of decentralization implies the distribution of all administrative and managerial powers to those that are either within the national competence or the competence of locative/local communities. At the same time, along with part of the functions from the central government to the local also the resource for their performance must be

\footnotetext{
${ }^{1}$ Novyi tlumachnyi slovnyk ukrainskoi movy (2006) [A new interpretative dictionary of the Ukrainian language]. Kyiv: AKONIT, Tom 1. 535 p.
} 
transferred, so the delegation of powers should be accompanied by adequate financial support.

In the hierarchy of decentralization signs "financial decentralization" is a generic, system-forming concept that encompasses budgetary and fiscal types that aim to strengthen and effectively budgetary potential usage as a result of budgetary system decentralization.

The provision of public goods and services at different levels of government that best meet the needs of the population of a country or a certain territory contributes to improving the efficiency of the functioning of the state budget system. According to W. Oates decentralization theorem, efficient spending of public funds on public goods and services can provide the level of power closest to the consumers of budget services, and the benefits of them cover the cost they are prepared to pay in society ${ }^{2}$.

Budget decentralization refers to the powers (functions, competences, responsibilities) and financial resources delegation process for their execution from central authorities to local ones. Several scholars believe that fiscal decentralization is a significant mechanism of budgetary federalism. Budgetary federalism, the basic principles of which are laid down in the works of C. Tiebout ${ }^{3}, \mathrm{~W}$. Oates ${ }^{4}, \mathrm{R}$. Masgrave ${ }^{5}$, and others, is a complex multifaceted concept. Despite the lack of consensus among researchers, everyone agrees that the decision of the authorities to provide public goods must satisfy local/locative needs. This means that in the context of local budgets independence, financial and budgetary relations organization between the centre and local authorities must coordinate and reconcile their interests, coordinate the provision of public goods and services of proper quality, ensure the territories development.

Reconciling and combining the interests of central and local authorities involves ensuring fairness and transparency in the allocation and redistribution of public finances, the organization of intergovernmental budgetary relations, the consideration of territorial disparities in the development of regions, the potential and opportunities / conditions of its disclosure.

Budget decentralization is the balancing of the state budget system by coordinating the volume of all types of local budget revenues and the

\footnotetext{
${ }^{2}$ Oates, W. E. (1972). Fiscal Federalism. Harcourt Brace: New York, 318 p.

${ }^{3}$ Tiebout, C. M. (1956). A Pure Theory of Local Expenditures. Journal of Politicai Economy, Vol. 64 (5), pp. 416-424.

${ }^{4}$ Oates, W. E. (1972). Fiscal Federalism. Harcourt Brace: New York, 318 p.

${ }^{5}$ Masgrave, R. A. (1959). The Theory of Public Finance. New York: McGraw-Hill Book Company, Inc., pp. $628-526$.
} 
expenditures amount for the implementation of delegated by the state functions, solving of certain territory social and economic development problems. Shifting revenues and lower-level expenditures while maintaining financial responsibility requires an optimal, appropriate distribution of powers between authorities and local governments, and increasing the of regions financial self-sufficiency.

In the context of fiscal decentralization, complex issues of financial autonomy and financial responsibility are being solved. The financial autonomy of the local self-government body is enshrined in the Budget Code of Ukraine and characterized as the right of autonomous, independent formation (including legally allowed formation of rates and conditions of payment of local taxes and fees), approval of local budgets, implementation of borrowing, execution of the assigned functions and administration of subordinate administration-territorial formation ${ }^{6}$. The basis for the financial autonomy of local self-government bodies is the sufficiency of funds to fulfil their own and delegated powers by local budgets types. Therefore, an integral aspect of budgetary decentralization is to strengthen its financial base - local budget revenues and enhance their impact on social and economic development. In this context, the role of budgetary policy as a system-forming institution of budgetary relations in influencing social and economic processes in the country and regions and its forms - income, expenditure, transfer, debt - Is increasing. I. Chugunov notes that budget policy is developed in budget process course, it provides for the definition of goals and objectives in finance, the development of a mechanism for the budget funds mobilization, the choice of directions for their use, the management of finances in the budget sector, budgetary instruments for regulating economic and social processes ${ }^{7}$.

Budget policy is becoming an active, important tool for the realization of strategic goals of social development and administrative-territorial entities, solving current problems, stimulating socio-economic development of territories. A prerequisite for sustainable development is usage of budgetary policy as one of the levers to promote territorial entities development, strengthen their financial, budgetary, tax potential, create conditions for its implementation, taking into account the economic, social and cultural status of administrative and territorial formation and maturity

\footnotetext{
${ }^{6}$ Biudzhetnyi kodeks Ukrainy vid 08.07.2010 [Budget Code of Ukraine from 08.07.2010]. № 2456-VI. URL: http://zakon0.rada.gov.ua/laws/show/2456-17

7 Chugunov I. Ya. (2005). Teoretychni osnovy systemy biudzhetnoho rehuliuvannia [Theoretical foundations of the system of budgetary regulation]. Kyiv: NDFI, 96 p. (in Ukrainian)
} 
of the institutional environment. In addition, budgetary policies at the local level should contribute to the structural adjustment and improvement of inter-regional, inter-sectoral and sectoral proportions.

An indispensable condition for effective budgetary decentralization is the extension of the competence of local governments to independently implement the budget process at the local level. Effective and reasonable forecasting, planning, formation, execution, control and audit of the local budget will promote compliance with budgetary discipline, budget process transparency and increase the responsibility of self-government bodies for achieving the planned results. D. Wildasin points out that the effectiveness of decentralized redistribution of budget resources is largely determined by the ability of local governments to provide effectively certain public services to people ${ }^{8}$.

Local budget revenues under conditions of budgetary decentralization are increasingly dependent on the tax potential of a territory. Strengthening tax potential because of significant component of fiscal decentralization tax decentralization, requires the transfer to the local level of authority to establish, administer, collect, dispose of a legislatively designated share of tax revenues and fees - the financial basis for local budgeting. That is, local taxes and fees should be the main source of local budget expenditures, since public services must be paid for by their customers. At the same time, all members of society should be equal in the right to social welfare not less than the level of minimum social standards established in the country. In this context, the extension of financial autonomy and autonomy of local self-government bodies implies the fulfilment at the territorial level of both own and delegated (state-delegated to the local level) functions.

Budget decentralization implies not only a complex process of allocation of functions, powers, financial resources, but also compliance with the principle of responsibility for their use. Regarding financial (fiscal) responsibility, it should be noted that it should concern both selfgovernment bodies and citizens. The latter should understand (and the authorities - to demonstrate) the close relationship between the amount of taxes and fees paid to the budget and the amount and quality of public goods and services received at budget expense. To do this, it is necessary to increase people financial literacy, to develop tax culture (in particular, the

\footnotetext{
${ }^{8}$ Wildasin, D. E. (1996). Comment on "Fiscal Federalism and Decentralization: A Review of Some Efficiency and Macroeconomic Aspects" by Vito Tanzi. Annual World Bank Conference on Development Economics. Washington: World Bank, 323 p.
} 
obligation to pay taxes, avoid tax evasion due to shadow activity/employment), to increase the budget process transparency, to inform the community in a timely and accessible manner about the state and results of budget execution projects and programs implemented through local budgets and partnerships.

In addition, in view of foreign experience, territories development under conditions of budgetary decentralization implies active participation of the community in public sphere, creation of conditions and implementation of the policy of joint decision-making, which is integrated in the implementation of institutional changes for the purpose of conscious participation of citizens in cooperation with local authorities formulation, provision and implementation of responsible targeted solutions to address top priority local problems. It also involves public scrutiny, monitoring and evaluation of budgetary resources efficient usage. According to the researchers, community-based initiation of community-based development projects is particularly appropriate in the context of the immaturity of the institutional environment, institutional distortions (lack of competence, corruption, low levels of responsibility, passiveness of the authorities, etc.), post-crisis period ${ }^{9}$, and at the same time carries with it the dangers and threats to participatory democracy ${ }^{10}$. T. Alberich and A. Espadas, examining this issue on the example of Spain, point out that the reduction of community development projects and participation programs that took place during the crisis should be stopped, with education/knowledge and professional experience of citizens ${ }^{11}$.

The "Concept of reforming local self-government and territorial organization of government in Ukraine" identifies the following priority areas of budgetary decentralization: ensuring budgetary autonomy and financial autonomy of local budgets; encouraging communities to unite and form capable territorial communities; securing for local budgets stable sources of revenue and expanding the existing revenue base of local budgets; decentralization of expenditure powers and a clear division of competences, formed on the principle of subsidiarity; providing new types

\footnotetext{
9 Tanaca, S., Singh, J., Songeo, D. (2006). A review of community-driven development and its application to the Asian Development Bank. 100 p. URL: http://www.estudislocals.cat/wp-content/ uploads/2017/01/AreviewCDDtoADB.pdf

${ }^{10}$ Voznyak, H., Pelekhatyy, A. (2017). Participatory budgeting as a tool for the implementation of the fiscal policy of regional development of Ukraine. Economic Annals-XXI, Vol. 167(9-10), pp. 53-56.

11 Alberich, T., Espadas, M. Angeles (2014). Democracia, participation ciudadana y funciones del trabajo social [Democracy, citizen participation and funciones of social work]. Trabajo social global, Vol. 4 (6), pp. 3-30. URL: file:///D:/\%D0\%9C\%D0\%BE\%D0\%B8\%20\%D0\%B4\%D0\%BE\%D0\%BA\%D1\%83\% D0\% BC\%D0\%B5\%D0\%BD\%D1\%82\%D1\%8B/Downloads/GlobalSocialWork20144\%20(1).pdf.
} 
of transfers and strengthening the responsibility of line ministries for implementing public policy in the respective sectors; definition of a new mechanism of budgetary regulation and alignment.

State budget system decentralization, contributing to the real autonomy of local self-government, implies the improvement of forecasting and planning, the use in the budget process of the programtarget method of planning tools. Its progressiveness and advantages over other planning methods in the budget sphere allow to concentrate on the results of use of budgetary means, to ensure clarity and transparency of the budget process, to increase the managerial responsibility of executors while expanding the possibilities for decentralization of management and delegation of powers, to adapt, flexibly and responsibly and make timely adjustments.

Thus, for effective budgetary decentralization implementation, the following prerequisites are required:

- territorial communities, territories, regions consolidation;

- central and local authorities powers separation;

- ensuring the financial capacity of territorial communities and regions;

- financial responsibility of territorial communities, regions, population formation;

- implementation and use of progressive management and planning methods in the budget process, widening the budget planning horizon.

Creating a financial foundation for local self-government in the context of the redistribution of power in the financial sector should also consider the potential risks of local budgets associated with economic transformations and economic instability.

\subsection{Financial aspects of deepening budgetary decentralization in Ukraine}

Active reform of power decentralization in Ukraine, which is based on budgetary decentralization, has begun since the beginning of 2015. For this purpose, several changes were introduced to the Budget Code of Ukraine (BCU), the Tax Code of Ukraine (TCU) and some legislative acts of Ukraine on ensuring the budget revenues balance. The reform process intends to strengthen local self-government bodies role and capacity to promote sustainable development of the regions and increase the wellbeing of citizens, which implies the formation and implementation of responsible and effective budgetary policies at the regional level, 
determining the directions of its influence on the promotion of balanced social and economic development. As a result of the decentralization reform, the capacity of local self-government bodies of Ukraine should be increased independently, at the expense of their own resources, to resolve issues of local importance, which is ensured by transferring additional budgetary powers and securing stable sources of revenue for their implementation.

Increasing sources of local budgets revenue base formation is enshrined in legislation by transferring certain types of revenues from the state budget, introducing changes and expanding the tax base, etc. ${ }^{12}$ Local governments are empowered to increase their fiscal independence, by setting local tax rates and levies, benefits. In addition, the system of balancing of all local budgets was changed by introducing a system of horizontal levelling of taxability of territories, depending on the level of income per capita. Educational and medical subsidies from the state budget have been introduced to cover expenditures on state delegated powers in education and health care ${ }^{13}$. The analysis shows that the level of budgetary decentralization in Ukraine is gradually increasing, with about $15 \%$ of gross domestic product distributed through local budgets (Table 1).

Analysis of local budgets for 2015-2018 implementation suggests that the results of budgetary decentralization reform in Ukraine four years implementation produce some positive results. Thus, changes were made to the composition and structure of tax revenues to local budgets.

In fact, they were reformatted, consolidated and the proportions of distribution between the state and local budgets and between the local budgets themselves changed. During 2015-2018, tax revenues increased by the following types of taxes: PIT, single tax, and environmental tax (Table 2).

The data in Table 2 show that, despite directing the PIT share to the state budget, it remains the most important component in the structure of local government tax revenues. The volume of PIT income for 2018 amounted to $138064,4 \mathrm{mln}$. UAH, the level of performance of the annual indicator approved by local councils is $101,1 \%$. Land tax is a significant

\footnotetext{
12 Pro vnesennia zmin do Podatkovoho kodeksu Ukrainy ta deiakykh zakonodavchykh aktiv Ukrainy shchodo zabezpechennia zbalansovanosti biudzhetnykh nadkhodzhen u 2016 rotsi [On Amendments to the Tax Code of Ukraine and Certain Legislative Acts of Ukraine on Balancing Budget Revenues in 2016]: Zakon Ukrainy vid 24.12.2015 № 909-VIII. URL: http://zakon2.rada.gov.ua/laws/show/909-19

${ }^{13}$ Pro vnesennia zmin do Biudzhetnoho kodeksu Ukrainy shchodo reformy mizhbiudzhetnykh vidnosyn: Zakon Ukrainy vid 28.12.2014 [On Amendments to the Budget Code of Ukraine on Intergovernmental Relations Reform: Law of Ukraine of 28.12.2014] № 79-VIII. URL: http://zakon2.rada.gov.ua/laws/show/
} 
part of the revenue structure of local budgets (till 2015 - payment for land). After a sharp fall in 2013, its share increased and fluctuates in the next years within $15 \%$.

Table 1

\section{Dynamics of the state and local budgets of Ukraine revenues share in $\mathrm{GDP}^{14}, \%$}

\begin{tabular}{|c|c|c|c|c|c|c|c|c|c|c|c|c|c|}
\hline & ठ̊ & $\widehat{\overbrace{}}$ & $\stackrel{\infty}{8}$ & ஜे & $\stackrel{\circ}{\circ}$ & $\overline{\vec{i}}$ & $\stackrel{2}{\stackrel{d}{~}}$ & $\stackrel{m}{\stackrel{n}{~}}$ & $\stackrel{d}{\stackrel{i}{d}}$ & ஜ̊ & $\stackrel{0}{\stackrel{2}{ }}$ & 홍 & $\stackrel{\infty}{\stackrel{\sim}{~}}$ \\
\hline \begin{tabular}{|l|}
$\begin{array}{l}\text { National } \\
\text { budget }\end{array}$ \\
\end{tabular} & 24,5 & 23,0 & 24,4 & 24,7 & 22,2 & 24,2 & 24,5 & 23,4 & 22,8 & 27,1 & 25,9 & 30,4 & 30,0 \\
\hline Local budgets & 13,4 & 14,4 & 13,8 & 13,9 & 13,9 & 13,1 & 15,1 & 14,4 & 14,6 & 14,9 & 15,4 & 15,0 & 15,6 \\
\hline Own income & 6,8 & 7,6 & 7,1 & 6,9 & 6,6 & 5,8 & 6,3 & 6,4 & 5,1 & 5,1 & 6,2 & 6,5 & 7,1 \\
\hline $\begin{array}{l}\text { Intergovern- } \\
\text { mental } \\
\text { transfers }\end{array}$ & 6,6 & 6,8 & 6,7 & 7,0 & 7,3 & 7,3 & 8,8 & 8,0 & 8,3 & 8,8 & 8,2 & 7,7 & 8,6 \\
\hline
\end{tabular}

Table 2

\section{Structure of tax revenues of local budgets in Ukraine ${ }^{15}$, 2014-2018}

\begin{tabular}{|l|c|c|c|c|c|}
\hline \multicolumn{1}{|c|}{ Income } & 2014 & 2015 & 2016 & 2017 & 2018 \\
\hline $\begin{array}{l}\text { Total tax collections, } \\
\text { including: }\end{array}$ & 100 & 100 & 100 & 100 & 100 \\
\hline $\begin{array}{l}\text { Personal Income Tax } \\
\text { (PIT) }\end{array}$ & 68,0 & 55,9 & 53,8 & 55,1 & 60,3 \\
\hline Excise tax & - & 7,7 & 7,8 & 6,6 & 6,3 \\
\hline Corporate income tax & 0,4 & 4,4 & 4,1 & 3,2 & 3,0 \\
\hline Land tax and rent & 13,8 & 15,1 & 15,9 & 13,6 & 13,9 \\
\hline Single tax & 8,5 & 11,2 & 11,7 & 11,1 & 14,1 \\
\hline Environmental tax & 1,4 & 1,6 & 2,3 & 1,3 & 1,6 \\
\hline Other taxes and fees & 7,9 & 4,1 & 4,4 & 9,1 & 7,1 \\
\hline
\end{tabular}

Revenues from the land tax for 2018 amounted to 27 319,1 mln. $\mathrm{UAH}$, the level of implementation of the annual indicator approved by local councils - 99,1\%. In 2018, out of 18 regions of Ukraine, only 5 regions provided more than $10 \%$ increase in land tax, which is above the national average (3.6\%), a decrease compared to the previous year -

\footnotetext{
${ }^{14}$ The author calculated according to the data: Derzhavna kaznacheiska sluzhba Ukrainy. Zvitnist pro vykonannia biudzhetiv Ofitsiinyi sait. URL: http://www.treasury.gov.ua/main/uk/doccatalog/list? currDir $=146477$

${ }^{15}$ The author calculated according to the data: Derzhavna kaznacheiska sluzhba Ukrainy. Zvitnist pro vykonannia biudzhetiv [State Treasury Service of Ukraine. Budget Execution Reporting]. Ofitsiinyi sait. URL: http://www.treasury.gov.ua/main/uk/doccatalog/list?currDir=146477
} 
Dnipropetrovsk (-6.4\%), Zakarpatska (-3.2\%) and Zaporizhzhia (-0.7\%) regions. In general, the share of land tax in local government tax revenues is decreasing, indicating the need for improved planning and reviewing benefits feasibility. Excise tax receipts are volatile and change as a result of changes in legislation and several other factors. The share of the single tax, which since 2011 has been included in the local budgets, is increasing. Its actual receipts for 2018 amounted to $29487,7 \mathrm{mln}$. UAH, an increase of revenues against 2017 is $26,5 \%$ or $6186,2 \mathrm{mln}$. UAH more. The potential of the real estate tax other than land is not fully realized today, despite the tax base expansion. We see the main reason in its administration shortcomings ${ }^{16}$.

A significant result of decentralization is the overall increase of local taxes and fees share in local budget revenues, which together with intergovernmental transfers contributes to improving their financial sustainability. If before the reform began - in 2014, the share of local taxes and fees was $9.2 \%$ in the structure of local budget revenues, in 2015 due to changes in the budget and tax legislation $-27.5 \%$, in $2016-28.8 \%$ in $2018-30 \%$. In addition, the structure of non-tax revenues of local budgets shows an increase of administrative fees and payments share - from $13.8 \%$ in 2014 to $22.0 \%$ in 2018 (8.2\%).

Thus, a significant increase of local taxes and levies share in local budget revenues is an achievement of budgetary decentralization, while at the same time, an increase of intergovernmental transfers share in local budget revenues indicates a low level of local budgets financial autonomy. Thus, in 2018, intergovernmental budget transfers to local budgets amounted to $298.9 \mathrm{bln}$. UAH (in terms of own revenues $-263.5 \mathrm{bln}$. UAH), whereas in 2014 - UAH 130.6 bln. (own revenues - $101.1 \mathrm{bln}$. $\mathrm{UAH})$. That is, local budgets are still heavily dependent on financial support from the centre, and this problem needs to be addressed. The budgetary practice of implementing measures for budgetary decentralization of foreign countries shows that legislative regulation of intergovernmental relations and responsibilities of the central government and local self-government, clearer and justified separation of their powers, creating preconditions for their financial security, involvement of the community, and compliance positive trends in local budgeting and spending accordingly.

\footnotetext{
16 Lysiak, L. V., \& Hrabchuk, O. M. (2018). Zmitsnennia biudzhetnoho potentsialu mistsevykh biudzhetiv Ukrainy $\mathrm{v}$ umovakh finansovoi detsentralizatsii [Strengthening the budgetary potential of Ukraine's local budgets in the context of financial decentralization]. Problems of economy, 1, 294-299.
} 
Effective fiscal decentralization requires the consolidation of territorial communities, territories, regions, the pooling of local budget resources, the real increase of local taxes and fees, which will contribute to the financial capacity of the united territorial communities (UTC) in solving local development problems. I. Lunina notes that in most territorial communities of Ukraine, especially those with a small population, about $80 \%$ of the budget's expenditures go to management ${ }^{17}$. The researcher estimated that out of 12 thousand territorial communities, $40 \%$ had a population less than 1000 and $10 \%$ - less than 500. That is, community unification will also solve the problem of reducing administrative costs, but most importantly it will contribute to financial capacity accumulation, creation of conditions and opportunities for stimulating territorial entities development.

The process of forming an UTCs in the country has been intensified due to a number of financial and institutional factors, including the legislative regulation of community associations, changes in tax legislation, financial incentives, and in addition, non-economic factors, among which are psychological, socio-cultural and other. In 2015, 159 united communities were formed, and the following year received direct intergovernmental budgetary relations. In 2016, the first elections were held in 207 UTCs, which is 1.3 times more than in 2015. As a result, in 2015-2016, 366 UTCs were formed, and in 2017, another 299 UTCs. The 665 UTCs united in 3180 territorial communities. In 2018, the number of UTCs increased to 874, bringing together 4004 territorial communities. Revenues of 665 UTCs in 2018 increased by 62.5\% compared to 2017 (in monetary terms - by $6.5 \mathrm{bln}$. UAH) and amounted to $17 \mathrm{bln}$. UAH. Due to the active integration of territorial communities in 2015-2018, their income base has expanded. The process of unification of territorial communities is ongoing and the opportunity to summarize their financial activities has emerged (Table 3 ).

The data grouped in Table. 3 provide an opportunity to draw the following generalizations and preliminary conclusions. The own revenues of local budgets for one resident per capita have the highest and lowest values in group 4 (compared to all groups of UTC). Despite the fact that the upper limit of own income per capita is lower in group 1, at the same time it has the lowest level of subsidy, and in terms of expenditures for the maintenance of the management apparatus in the financial resources of the UTCs, it is inferior to group 2.

\footnotetext{
${ }^{17}$ Lunina, I.O. (2014). Biudzhetna detsentralizatsiia: tsili ta napriamy reform [Budget decentralization: goals and directions of reform]. Ukraine economy, 11, 61-75.
} 
Table 3

Selected financial performance indicators of 665 UTCs in $2018^{18}$

\begin{tabular}{|l|c|c|c|c|}
\hline \multirow{2}{*}{$\begin{array}{c}\text { Indicators } \\
\text { (range [max } \div \text { min]) }\end{array}$} & \multicolumn{4}{|c|}{ UTC with population, thousands of inhabitants } \\
\cline { 2 - 5 } & $\begin{array}{c}>15000 \\
\text { (group 1, } \\
87 \text { UTC) }\end{array}$ & $\begin{array}{c}10000- \\
15000 \\
\text { (group 2, } \\
103 \text { UTC) }\end{array}$ & $\begin{array}{c}5000-10000 \\
\text { (group 3, } \\
\text { 227 UTC) }\end{array}$ & $\begin{array}{c}<5000 \\
\text { group 4, } \\
248 \text { UTC) }\end{array}$ \\
\hline $\begin{array}{l}\text { Own income per inhabitant, } \\
\text { thousand UAH }\end{array}$ & $6,04 \div 0,94$ & $21,69 \div 0,74$ & $17,58 \div 0,63$ & $25,50 \div 0,60$ \\
\hline Budget subsidy level, \% & $47,6 \div(-8,0)$ & $52,9 \div(-21,1)$ & $57,9 \div(-24,0)$ & $60,3 \div(-28,3)$ \\
\hline $\begin{array}{l}\text { Share of expenditures for } \\
\text { maintenance of management } \\
\text { apparatus in financial } \\
\text { resources of UTC, \% }\end{array}$ & $58,9 \div 22,8$ & $49,3 \div 8,6$ & $87,3 \div 6,8$ & $76,6 \div 9,5$ \\
\hline $\begin{array}{l}\text { Capital expenditures per } \\
\text { capita, UAH }\end{array}$ & $3,27 \div 0,43$ & $9,76 \div 0,46$ & $6,65 \div 0,20$ & $11,56 \div 0,24$ \\
\hline
\end{tabular}

The upper and lower limits of the range of the level of subsidy the budgets are the highest in group 4, so the budgets of the UTCs with the smallest population depend most on the state budget. At the same time, they are investment active. Thus, the upper limit on capital expenditures per capita is the highest in group 4, the lowest in group 1. The upper boundary of the share of expenditures on the management of the UTCs financial resources is the highest in group 3 (which is 10.7 percentage points higher than in group 4), the lowest - in group 2 (which is 9.6 percentage points lower than in group 1). Groups 1 and 2, combining respectively 87 and 103 UTCs with the largest population (more than 10,000 people each), have the best thresholds compared to groups 3 and 4, where the population is smaller. It should also be noted that the comparative assessment of individual financial performance indicators of an UTCs does not allow the full identification of deeper financial problems (considering the grouping UTCs by quantitative characteristics). Thus, UTC population is important and the enlargement of territorial communities allows, under all other things being equal, to reduce administrative costs, at the same time it requires effective budgetary policy formation, determining the priorities of development, taking into account the characteristics and problems of territorial communities, the state of development of real sector, entrepreneurial activity, institutional factors, etc. Given that budgetary equalization is now based on revenue estimates

18 By the author according to the data: Initsiatyvy "Detsentralizatsiia". Derzhavnyi portal [Decentralization Initiatives. State portal]. URL: https://decentralization.gov.ua 
rather than local budget expenditures, this encourages territorial communities to develop the local economy and business sector ${ }^{19}$, thus strengthening the local budgets' revenue base.

Budget decentralization reform has led to change in the structure of local budget expenditures. The share of expenditures for the exercise of self-governing powers has increased, which testifies to the increase of spending autonomy of local budgets and creates prerequisites for ensuring the efficiency of the use of budgetary resources at the local level, provided their optimal distribution. Traditionally, the dominant share of local budget expenditures is social and cultural expenditure. Expenditure on social protection and social welfare accounts for the largest share. Expenditure on education, health care, economic activity, housing and communal services has increased ${ }^{20}$. However, the issue of lack of financial resources to local budgets for their own and delegated powers retained. Ensuring that the financial resource is in line with the actual needs of local budgets to spend on their own and delegated powers requires additional transfers from the state budget. In order to ensure budgetary balance, targeted subventions and basic local budget subsidy were introduced in the context of fiscal decentralization reform. The new system of budgetary balancing made it possible to leave most of the funds in the field, and local governments gained more independence when making management decisions. In 2017 and 2018, an additional grant for education and health care facilities is provided for all local budgets that have direct intergovernmental budgetary relationships. The urgent issue in this regard is the development and approval of scientifically grounded state social standards for education, health care, etc., which will optimize the number and structure of budgetary institutions, will ensure the efficiency of planning and use of local budgets, compliance with standards budget sector security to meet the real needs of consumers, reduce the budget deficit to finance the delegated powers. An important aspect is the introduction of an effective mechanism for social benefits targeted provision.

\footnotetext{
19 Analitychna dopovid do shchorichnoho Poslannia Prezydenta Ukrainy do Verkhovnoi Rady Ukrainy "Pro vnutrishnie ta zovnishnie stanovyshche Ukrainy v 2018 rotsi" [Analytical Report to the Annual Message of the President of Ukraine to the Verkhovna Rada of Ukraine "On Internal and External Situation of Ukraine in 2018”]. Rozdil 3. Kyiv: NISD, 1289. URL: http://www.niss.gov.ua/articles/3143/

${ }^{20}$ Pro vnesennia zmin do Podatkovoho kodeksu Ukrainy ta deiakykh zakonodavchykh aktiv Ukrainy shchodo zabezpechennia zbalansovanosti biudzhetnykh nadkhodzhen u 2016 rotsi [On amendments to the Tax Code of Ukraine and some legislative acts of Ukraine on ensuring the balance of budget revenues in 2016]: Zakon Ukrainy vid 24.12.2015 № 909-VIII. URL: http://zakon2.rada.gov.ua/laws/show/909-19
} 
Local self-government bodies also have the right to freely manage balances of educational and medical subventions. The new budgetary equalization system has increased the balance of local budgets (about $13 \%$ of local budgets have become fully balanced in 2018). The number of local donor budgets has increased to $17 \%$, which indicates a strengthening of their financial, and fiscal, capacity. It should be noted that the new equalization system is stimulating, since only $50 \%$ of donor budget funds are withdrawn, and in order to equalize the capacity of other territories, not for the benefit of the state budget ${ }^{21}$.

An important positive factor in the implementation of fiscal decentralization reform was an increase in local budget investment resources. Along with increasing the amount of capital expenditures of local budgets, an important factor in ensuring regional development is the State Regional Development Fund (SRDF) funds, which are used to implement investment programs and regional development projects (including projects of cooperation and voluntary association of territorial communities). The total number of projects today - 19038, the scope of which are: energy (gas, heat, electrical) provision, major road repairs, modernization of heating systems for schools and kindergartens, sports infrastructure (construction of sports grounds, stadiums), improvement and more $^{22}$. The problem that arises from the regional programs and projects implementation is the poor quality of their preparation, which leads to decrease in the efficiency of the funds from the ERDF usage. Preparation and implementation of investment projects and programs should not take place spontaneously, but in line with the socio-economic strategy and priorities of territorial development, be discussed by the public, and for their implementation - to involve socially responsible business based on partnership.

\section{CONCLUSIONS}

Ensuring real decentralization processes, granting broad powers to local governments, whose implementation will be ensured on a financial basis, and powers delegated to local governments, should be provided with financial resources. To improve the condition of local budgets and increase

21 Lysiak L.V. (2009).Biudzhetna polityka u systemi derzhavnoho rehuliuvannia sotsialnoekonomichnoho rozvytku Ukrainy [Budget policy in the system of state regulation of socio-economic development of Ukraine]. Kyiv: DNNU AFU, 600 p.

${ }^{22}$ Perelik proektiv Derzhavnoho fondu rehionalnoho rozvytku [List of projects of the State Regional Development Fund]. URL: http://dfrr.minregion.gov.ua/Projects-list. 
their financial stability and autonomy, it is necessary to formulate and implement effective budgetary policies in the area of income and expenditure.

In the current context of deepening decentralization through sound budgetary policies, local budgets can ensure their financial sustainability and autonomy. Currently, there is dependence on intergovernmental transfers of local budgets, there is a discrepancy between revenues and expenditures of budgets, the powers entrusted to local budgets and their financial support, which shows that there is practically no autonomy. Local taxes and levies should be introduced at the same time as reducing unemployment and improving economic dynamics, involving communities in discussing such measures and justifying decisions.

Implementation of budgetary decentralization reform and ensuring the effectiveness of the mechanism of budgetary regulation of socio-economic development requires further expansion of self-government bodies' rights, strengthening their budgetary autonomy and determining responsibility. This requires the development and approval of scientifically grounded state social standards for the social sectors, which will increase the efficiency of planning and use of local budgets, compliance with the standards of budgetary sectoral security to the real needs of consumers. An important aspect is the introduction of an effective mechanism for targeted provision of social benefits, hence their financial evaluation.

In the context of modern reforming (decentralization of budgetary relations, extension of budgetary rights of local authorities and granting autonomy in budgetary powers to self-government bodies) more detailed planning and control, budgetary policy measures are needed, that will help to increase the responsibility of self-government bodies for efficient spending of budgetary funds, implementation of properly justified investment projects and programs on the basis of partnership, improve the quality of administrative and social services to people.

\section{SUMMARY}

Budgetary decentralization processes in the aspect of local budget development, expansion of tax potential of generating budget revenues of the united territorial communities and expenditure planning improvement are relevant at the current stage of social transformation and reform.

The purpose of this study is to analyse the theoretical foundations of budgetary decentralization, to evaluate the process of its practical 
implementation and to outline the ways to strengthen local budgets in the face of deepening reforms and economic transformation in Ukraine.

The essence of decentralization, financial decentralization, including budgetary and taxation is revealed. It is shown that effective budgetary decentralization implementation requires the formation of certain preconditions in the country. The level of budgetary decentralization in Ukraine has been determined. The analysis of tax revenues as the most important source of local budgets formation and identified the reserves of territorial entities tax potential strengthening.

Achievements and problems of budget decentralization in Ukraine are shown. The financial indicators of the united territorial communities, grouped by population, are estimated. The peculiarities of budgetary decentralization in Ukraine and factors affecting the financial capacity of the united territorial communities are revealed.

The problems that arise in connection with the implementation of local investment projects and programs and the possibilities of their solution are outlined. Budget policy measures have been identified in the light of improving budgetary efficiency.

\section{REFERENCES}

1. Novyi tlumachnyi slovnyk ukrainskoi movy (2006) [A new interpretative dictionary of the Ukrainian language]. Kyiv : AKONIT, T. 1. 535 p. (in Ukrainian)

2. Oates, W. E. (1972). Fiscal Federalism. Harcourt Brace : New York, $318 \mathrm{p}$.

3. Tiebout, C. M. (1956). A pure theory of local expenditures. Journal of Politicai Economy, vol. 64 (5), pp. 416-424.

4. Masgrave, R. A. (1959). The theory of public finance. New York: McGraw-Hill Book Company, Inc., pp. 628-526.

5. Biudzhetnyi kodeks Ukrainy vid 08.07.2010 [Budget Code of Ukraine from 08.07.2010]. № 2456-VI. URL: http://zakon0.rada.gov.ua/ laws/show/2456-17

6. Chugunov, I. Ya. (2005). Teoretychni osnovy systemy biudzhetnoho rehuliuvannia [Theoretical foundations of the system of budgetary regulation]. Kyiv: NDFI, 96 p. (in Ukrainian)

7. Wildasin, D. E. (1996). Comment on "Fiscal Federalism and decentralization: a review of some efficiency and macroeconomic aspects" by Vito Tanzi. Annual World Bank Conference on Development Economics. Washington: World Bank, 323 p. 
8. Tanaca, S., Singh, J., \& Songeo, D. (2006). A review of community-driven development and its application to the Asian Development Bank. 100 p. URL: http://www.estudislocals.cat/wp-content/ uploads/2017/01/AreviewCDDtoADB.pdf

9. Voznyak, H., \& Pelekhatyy, A. (2017). Participatory budgeting as a tool for the implementation of the fiscal policy of regional development of Ukraine. Economic Annals-XXI, vol. 167(9-10), pp. 53-56.

10. Alberich, T., \& Espadas, M. Angeles (2014). Democracia, participation ciudadana y funciones del trabajo social [Democracy, citizen participation and funciones of social work]. Trabajo social global, vol. 4(6), pp. 3-30.

11. Pro vnesennia zmin do Biudzhetnoho kodeksu Ukrainy shchodo reformy mizhbiudzhetnykh vidnosyn [On Amendments to the Budget Code of Ukraine on Intergovernmental Relations Reform]. Zakon Ukrainy vid 28.12.2014 № 79-VIII. URL: http://zakon2.rada.gov.ua/laws/show/7919 (in Ukrainian)

12. Pro vnesennia zmin do Podatkovoho kodeksu Ukrainy ta deiakykh zakonodavchykh aktiv Ukrainy shchodo zabezpechennia zbalansovanosti biudzhetnykh nadkhodzhen u 2016 rotsi [On Amendments to the Tax Code of Ukraine and Certain Legislative Acts of Ukraine on Balancing Budget Revenues in 2016]. Zakon Ukrainy vid 24.12.2015 № 909-VIII. URL: http://zakon2.rada.gov.ua/laws/show/909-19 (in Ukrainian)

13. Derzhavna kaznacheiska sluzhba Ukrainy. Zvitnist pro vykonannia biudzhetiv [State Treasury Service of Ukraine. Budget Execution Reporting]. Ofitsiinyi sait. URL: http://www.treasury.gov.ua/ main/uk/doccatalog/list?currDir=146477 (in Ukrainian)

14. Lysiak, L. V., \& Hrabchuk, O. M. (2018). Zmitsnennia biudzhetnoho potentsialu mistsevykh biudzhetiv Ukrainy $\mathrm{v}$ umovakh finansovoi detsentralizatsii [Strengthening the budgetary potential of Ukraine's local budgets in the context of financial decentralization]. Problems of economy, vol. 1, pp. 294-299. (in Ukrainian)

15. Lunina, I. O. (2014). Biudzhetna detsentralizatsiia: tsili ta napriamy reform [Budget decentralization: goals and directions of reform]. Ukraine economy, vol. 11, pp. 61-75. (in Ukrainian)

16. Initsiatyvy "Detsentralizatsiia". Derzhavnyi portal. [Decentralization Initiatives. State portal]. URL: https://decentralization.gov.ua (in Ukrainian)

17. Analitychna dopovid do shchorichnoho Poslannia Prezydenta Ukrainy do Verkhovnoi Rady Ukrainy "Pro vnutrishnie ta zovnishnie 
stanovyshche Ukrainy v 2018 rotsi" [Analytical Report to the Annual Message of the President of Ukraine to the Verkhovna Rada of Ukraine "On Internal and External Situation of Ukraine in 2018"]. Rozdil 3. Kyiv: NISD, 1289. URL: http://www.niss.gov.ua/articles/3143 (in Ukrainian)

18. Lysiak, L. V. (2009). Biudzhetna polityka u systemi derzhavnoho rehuliuvannia sotsialno-ekonomichnoho rozvytku Ukrainy [Budget policy in the system of state regulation of socio-economic development of Ukraine]. Kyiv : DNNU AFU, 600 p. (in Ukrainian)

19. Perelik proektiv Derzhavnoho fondu rehionalnoho rozvytku [List of projects of the State Regional Development Fund]. URL: http://dfrr.minregion.gov.ua/Projects-list (in Ukrainian)

\section{Information about the author:} Lysiak L. V.

Doctor of Sciences (Economic), Professor, Professor of the Department of State, Local and Corporate Finance, University of Customs and Finance, Ukraine 